\title{
Analysis of FUS, PFN2, TDP-43, and PLS3 as potential disease severity modifiers in spinal muscular atrophy
}

Renske I. Wadman, MD, PhD,* Marc D. Jansen, BS, * Chantall A.D. Curial, BS, Ewout J.N. Groen, PhD, Marloes Stam, MD, Camiel A. Wijngaarde, MD, Jelena Medic, BS, Peter Sodaar, BS, Kristel R. van Eijk, PhD, Manon M.H. Huibers, PhD, Joyce van Kuik, BS, Henny H. Lemmink, MD, PhD, Wouter van Rheenen, MD, PhD, Jan Herman Veldink, MD, PhD, Leonard H. van den Berg, MD, PhD, and W. Ludo van der Pol, MD, PhD

Neurol Genet 2020;6:e386. doi:10.1212/NXG.0000000000000386

\section{Abstract \\ Objective}

To investigate mutations in genes that are potential modifiers of spinal muscular atrophy (SMA) severity.

\section{Methods}

We performed a hypothesis-based search into the presence of variants in fused in sarcoma (FUS), transactive response DNA-binding protein 43 (TDP-43), plastin 3 (PLS3), and profilin 2 (PFN2) in a cohort of 153 patients with SMA types 1-4, including 19 families. Variants were detected with targeted next-generation sequencing and confirmed with Sanger sequencing. Functional effects of the identified variants were analyzed in silico and for PLS3, by analyzing expression levels in peripheral blood.

\section{Results}

We identified 2 exonic variants in FUS exons 5 and 6 (p.R216C and p.S135N) in 2 unrelated patients, but clinical effects were not evident. We identified 8 intronic variants in PLS3 in 33 patients. Five $P L S 3$ variants (c. $1511+82 \mathrm{~T}>\mathrm{C}$; c. $748+130 \mathrm{G}>\mathrm{A}$; c. $367+182 \mathrm{C}>\mathrm{T}$; c.891-25T $>\mathrm{C}$ (rs145269469); c.1355+17A $>\mathrm{G}(\mathrm{rs} 150802596))$ potentially alter exonic splice silencer or exonic splice enhancer sites. The variant c. $367+182 \mathrm{C}>\mathrm{T}$, but not RNA expression levels, corresponded with a more severe phenotype in 1 family. However, this variant or level of PLS3 expression did not consistently correspond with a milder or more severe phenotype in other families or the overall cohort. We found 3 heterozygous, intronic variants in PFN2 and TDP-43 with no correlation with clinical phenotype or effects on splicing.

\section{Conclusions}

PLS3 and FUS sequence variants do not modify SMA severity at the population level. Specific variants in individual patients or families do not consistently correlate with disease severity.

\author{
Correspondence \\ Dr. Wadman \\ r.i.wadman@umcutrecht.nl
}

\footnotetext{
*R.I. Wadman and M.D. Jansen contributed equally to the manuscript.

From the Department of Neurology (R.I.W., M.D.J., C.A.D.C., E.J.N.G., M.S., C.A.W., J.M., P.S., K.R.E., W.R., J.H.V., L.H.B., W.L.P.), Brain Center Rudolf Magnus, University Medical Center Utrecht; Department of Pathology (M.M.H.H., J.K.), University Medical Center Utrecht; Department of Genetics (M.M.H.H.), University Medical Center Utrecht; and Department of Genetics (H.H.L.), University Medical Center Groningen, The Netherlands.

Go to Neurology.org/NG for full disclosures. Funding information is provided at the end of the article.

The Article Processing Charge was funded by the authors.

This is an open access article distributed under the terms of the Creative Commons Attribution-NonCommercial-NoDerivatives License 4.0 (CC BY-NC-ND), which permits downloading and sharing the work provided it is properly cited. The work cannot be changed in any way or used commercially without permission from the journal.
} 


\section{Glossary}

ESE = exonic splice enhancer; ESS = exonic splice silencer; FUS = fused in sarcoma; PFN2 = profilin 2; PLS3 = plastin 3; SMA = spinal muscular atrophy; SMN = survival motor neuron; TDP-43 = transactive response DNA-binding protein 43.

Proximal hereditary spinal muscular atrophy (SMA) is caused by homozygous deletion or mutation in the survival motor neuron 1 (SMN1) gene, combined with the presence of a variable number of copies of a related gene, SMN2. ${ }^{1}$ SMA has a striking spectrum of severity, ranging from severe antenatal to mild adult onset motor deficits. This variation is reflected by the widely used classification system that distinguishes types $0 / 1 \mathrm{a}-4$, based on the age at onset and the higher of 2 acquired motor milestones (e.g., sitting and walking independently). ${ }^{2}$

The backup SMN2 gene determines residual SMN protein levels in cells. ${ }^{3,9411}$ The SMN protein has multiple functions, including messenger RNA (mRNA) and ubiquitin homeostasis, ${ }^{4,5}$ axonal transport, ${ }^{6,7}$ and endocytosis. ${ }^{8}$ Differences in SMA severity are primarily explained by variation in copy numbers of $S M N 2$, but still $20 \%-40 \%$ of the clinical variability does not correspond with the $S M N 2$ copy number. ${ }^{9}$ SI $S M N 2$ point mutations, in particular c. $859 \mathrm{G}>\mathrm{C},{ }^{11}$ and possible epigenetic variation ${ }^{12}$ have been identified as additional severity modifying factors by changing amino acids, disrupting exonic splice enhancer (ESE) or exonic splice silencer (ESS), or altering expression of SMN in other ways. However, none of these intragenic SMN2 modifiers explain the full range of severity in SMA. It is therefore likely that there are additional modifiers of disease severity outside the SMN2 gene. ${ }^{10,13}$ Candidates include genes encoding proteins that interact with SMN in complexes or that have been shown to rescue SMN-dependent downstream cellular functions. For example, mutations in fused in sarcoma (FUS) can disrupt the axonal distribution pattern of SMN and were found to be associated with lower motor neuron syndromes. ${ }^{14}$ Moreover, transactive response DNA-binding protein 43 (TDP-43) is a major constituent of pathologic ubiquitinated protein aggregates in target tissues of patients with sporadic (lower) motor neuron disease. ${ }^{15,16}$ In addition, profilin 2 (PFN2) is important for preservation of cytoskeletal integrity and neuritogenesis. ${ }^{17,18}$ Of interest, each of these genes has also been implicated in other types of motor neuron disease and therefore provide possible functional links between SMA and other motor neuron diseases. ${ }^{15,16,19-21}$

The plastin 3 (PLS3) gene has been mapped to chromosome Xq23 and encodes an actin-binding protein. ${ }^{13}$ Although PLS3 probably does not directly interact with SMN, it represents an additional SMA severity modifying candidate gene because its overexpression was found in asymptomatic women with a homozygous SMN1 deletion who had male relatives with SMA type $3{ }^{13}$ Although the genetic background of PLS3 overexpression in individuals is unclear, PLS3 overexpression in experimental models for SMN deficiency reversed defects in axonogenesis and endocytosis. ${ }^{8,13,22}$
The incidence and effect of variation in these potential modifying genes in patients with SMA have not yet been explored in detail. Identification of these modifiers will help to dissect cellular processes and pathways that are affected by SMN deficiency and that may represent further therapeutic targets for SMA. We therefore investigated the presence of single nucleotide variants in PLS3, FUS, TDP-43, and PFN2 in a cohort of 153 patients with SMA types 1-4 to explore their potential role as SMA severity modifying genes. We included 19 families, 11 of which had sibs with differing degrees of severity.

\section{Methods}

We enrolled patients with SMA types 1-4 between September 2010 and August 2014. Methods are described in appendix e-1 (links.lww.com/NXG/A203).

\section{Standard protocol approvals, registrations, and patient consents}

The Medical Ethical Committee of the University Medical Center Utrecht approved the study protocol. This study was registered at the Dutch registry for clinical studies and trials (ccmo-online.nl).

\section{Data availability}

Anonymized data that support the findings of this study are available from the corresponding author on reasonable request.

\section{Results}

\section{Patients}

We included 153 patients. Characteristics of the participants are summarized in table 1.

All but 1 patient had homozygous deletion of at least exon 7 of $S M N 1$. One patient had a heterozygous deletion of $S M N 1$ and a point mutation in exon 4 (c.542A $>G)$, which created a new splice-donor site within exon 4 of SMN1 and an out-of-frame transcript (i.e., null allele).

Forty-two patients had a discordant phenotype (16 SMA type 1 with 3 or 4 SMN2 copies; 8 SMA type 2 with 2 or 4 SMN2 copies; 21 SMA type 3 with 3 or 5 SMN2 copies). Two patients with a discordant phenotype of SMA type 2 and only 2 SMN2 copies harbored the c.859G $>$ C mutation in SMN2 exon $7 .{ }^{11}$

We included 19 families encompassing a total of 35 siblings and first-degree relatives. Eleven (58\%) families, including 
Table 1 Patient characteristics

Variant analysis

\begin{tabular}{|c|c|c|c|c|c|c|c|}
\hline \multirow[b]{2}{*}{ SMA type } & \multicolumn{2}{|l|}{$1(n=25)$} & \multicolumn{2}{|l|}{$2(n=68)$} & \multicolumn{2}{|l|}{$3(n=53)$} & \multirow{2}{*}{$\frac{4(n=6)}{4(n=6)}$} \\
\hline & $1 b(n=9)$ & $1 c(n=16)$ & $2 a(n=38)$ & $2 b(n=30)$ & $3 a(n=27)$ & $3 b(n=26)$ & \\
\hline Sex F:M & $7: 2$ & $8: 8$ & $20: 18$ & $20: 10$ & $15: 12$ & $11: 15$ & $3: 3$ \\
\hline $\begin{array}{l}\text { Age at inclusion in years median } \\
\text { (range) }\end{array}$ & $\begin{array}{l}0.4 \\
(0.3-4.6)\end{array}$ & $\begin{array}{l}10.3 \\
(0.9-49.7)\end{array}$ & $\begin{array}{l}15.1 \\
(1.5-42.3)\end{array}$ & $\begin{array}{l}15.1 \\
(2.0-66.7)\end{array}$ & $\begin{array}{l}31.4 \\
(2.4-65.7)\end{array}$ & $\begin{array}{l}44.3 \\
(18.5-77.5)\end{array}$ & $\begin{array}{l}49.2 \\
(36-68.8)\end{array}$ \\
\hline $\begin{array}{l}\text { Age at onset in months median } \\
\text { (range) }\end{array}$ & $\begin{array}{l}1.0 \\
(1.0-3.0)\end{array}$ & $5.5(0.5-8.0)$ & $\begin{array}{l}8.8 \\
(3.5-42.0)\end{array}$ & $12(6.0-30.0)$ & $18.0(0-48.0)$ & $\begin{array}{l}87 \\
(46.0-210.0)\end{array}$ & $\begin{array}{l}411 \\
(246-516)\end{array}$ \\
\hline
\end{tabular}

SMN1 copy number, $\mathrm{n}$

\begin{tabular}{|c|c|c|c|c|c|c|c|}
\hline Homozygous deletion & 9 & 16 & 38 & 30 & 26 & 26 & 6 \\
\hline Heterozygous deletion & 0 & 0 & 0 & 0 & $1^{\mathrm{a}}$ & 0 & 0 \\
\hline \multicolumn{8}{|l|}{ SMN2 copy number $\mathrm{n}(\%)$} \\
\hline 2 & $9(100)$ & 0 & $1^{\mathrm{b}}(3)$ & $1^{b}(3)$ & $1(4)$ & 0 & 0 \\
\hline 3 & 0 & $15(94)$ & $35(92)$ & $25(84)$ & $15(56)$ & $3(12)$ & 0 \\
\hline 4 & 0 & $1(6)$ & $2(5)$ & $4(13)$ & $11(40)$ & $20(76)$ & $6(100)$ \\
\hline 5 & 0 & 0 & 0 & 0 & 0 & $3(12)$ & 0 \\
\hline \multicolumn{8}{|l|}{ RNA expression analysis } \\
\hline & \multicolumn{2}{|l|}{$1(n=1)$} & \multicolumn{2}{|l|}{$2(n=17)$} & \multicolumn{2}{|l|}{$3(n=29)$} & $4(n=3)$ \\
\hline SMA type & $1 b(n=0)$ & $1 c(n=1)$ & $2 a(n=11)$ & $2 b(n=6)$ & $3 a(n=14)$ & $3 b(n=15)$ & $4(n=3)$ \\
\hline Sex F:M & NA & $0: 1$ & $7: 4$ & $5: 1$ & $6: 8$ & $8: 7$ & $0: 3$ \\
\hline $\begin{array}{l}\text { Age at inclusion in years median } \\
\text { (range) }\end{array}$ & NA & $1.9(1.9)$ & $\begin{array}{l}17.6 \\
(1.5-38.7)\end{array}$ & $\begin{array}{l}24.7 \\
(3.7-66.7)\end{array}$ & $\begin{array}{l}26.3 \\
(2.9-65.7)\end{array}$ & $42.4(21.6-68)$ & $\begin{array}{l}41.9 \\
(36-47.5)\end{array}$ \\
\hline Age at onset in months median (range) & NA & $6.5(6.5)$ & $10(3.5-42.0)$ & $18(10.5-30.0)$ & $18.0(0-36.0)$ & $\begin{array}{l}72 \\
(36.0-210.0)\end{array}$ & $\begin{array}{l}294 \\
(246-366)\end{array}$ \\
\hline
\end{tabular}

SMN1 copy number, $\mathrm{n}$

\begin{tabular}{llllllll}
\hline Homozygous deletion & NA & 1 & 11 & 6 & 14 & 15 \\
\hline Heterozygous deletion & NA & 0 & 0 & 0 & 0 & 0 \\
\hline SMN2 copy number $\mathbf{n}(\%)$ & & & & & & \\
\hline $\mathbf{3}$ & NA & $1(100)$ & $10(91)$ & $4(66)$ & $5(36)$ & $1(7)$ & 0 \\
\hline $\mathbf{4}$ & NA & 0 & $1(9)$ & $2(34)$ & $9(64)$ & $13(86)$ & $3(100)$ \\
\hline $\mathbf{5}$ & NA & 0 & 0 & 0 & 0 & $1(7)$ & 0
\end{tabular}

Abbreviations: $\mathrm{n}=$ number; $\mathrm{NA}=$ not applicable; $\mathrm{SMA}=$ spinal muscular atrophy; $\mathrm{SMN}=$ survival motor neuron.

a Female patient with a heterozygous deletion of SMN1 and a point mutation in SMN1 exon 4 (c.542A $>$ G).

b Patients with a discordant phenotype according to SMN2 copy number harboring a point mutation in SMN2 exon 7 (c.859G $>$ C).

26 siblings and first-degree cousins, were discordant (e.g., brother with SMA type 3a and sister with SMA type 2b), despite similar SMN2 copy numbers in 17 of the 19 families (90\%).

\section{Variation in sequences of FUS, PFN2, TDP-43, and PLS3}

We identified 2 exonic variants in FUS, 8 intronic variants in $P L S 3,2$ intronic variants in PFN2, and 1 intronic variant in TDP-43. The full list of sequence variations in FUS, PFN2, $P L S 3$, and TDP-43 is provided in the supplementary file (table e-1, links.lww.com/NXG/A202).

\section{Variation in coding sequences of FUS}

We identified 2 different heterozygous missense sequence variants in FUS in 2 unrelated patients (table 2) and no intronic variants. One patient carried a mutation in FUS exon 6 (c.646C > T; p.R216C) that is predicted to be damaging (PolyPhen-2 score 0.997; sensitivity 0.41 ; specificity 0.98 ). This variant has been reported previously in patients with familial amyotrophic lateral sclerosis (ALS) with a lower motor neuron phenotype ${ }^{21,23}$ and patients with familial essential tremor. ${ }^{24}$ This patient has SMA type $1 \mathrm{c}$ and has 3 $S M N 2$ copies. Disease course did not differ from what was 
Table 2 Characteristics of 2 nonrelated patients with exonic variants in FUS

\begin{tabular}{lllllll}
\hline Exon & Variant $^{\mathbf{a}}$ & Effect $^{\mathbf{b}}$ & MAF & $\begin{array}{l}\text { SMN2 } \\
\text { copy } \\
\text { number }\end{array}$ & Observed SMA type & Expected SMA type $^{\mathbf{c}}$ \\
\hline $\mathbf{6}$ & $\begin{array}{l}\text { c.646C>T; } \\
\text { p.R216C }\end{array}$ & $\begin{array}{l}\text { Possibly } \\
\text { damaging }\end{array}$ & 0.01 & 3 & $\begin{array}{l}\text { 1c; onset at } 4 \text { mo of age. Highest acquired motor } \\
\text { milestones: lifting head in prone position. }\end{array}$ & $\begin{array}{l}\text { 1c: according to age at onset combined } \\
\text { with } 3 \text { SMN2 copies }\end{array}$ \\
\hline $\mathbf{5}$ & $\begin{array}{l}\text { c.404G>A; } \\
\text { p.S135N }\end{array}$ & Benign & 0.04 & 3 & $\begin{array}{l}\text { 2a; age at onset } 6 \text { mo. Sits unsupported, never able } \\
\text { to stand or walk with support. Start noninvasive } \\
\text { respiratory support at 12 } \mathrm{y} .\end{array}$ & $\begin{array}{l}\text { 2; brother with } 3 S M N 2, \text { and no FUS variant } \\
\text { has a 2b phenotype and no respiratory } \\
\text { support at age 26 } \mathrm{y} .\end{array}$ \\
\hline
\end{tabular}

Abbreviations: FUS = fused in sarcoma; MAF = mean allele frequency, given in \%; SMN = survival motor neuron; SMA = spinal muscular atrophy.

${ }^{a}$ Both variants were heterozygous.

${ }^{\mathrm{b}}$ Predicted possible effect of an amino acid substitution on the structure and function of a human protein by PolyPhen-2.

c Expected phenotype based on SMN2 copy number.

expected in SMA type 1c with 3 SMN2 copies. Age at onset was 4 months, when she lost the ability to lift her head in prone position. She has never acquired the ability to roll over or sit without support. At the time of inclusion, she was aged 13 years and still without respiratory support, despite episodes of pneumonia. This patient had a postural tremor that was not more pronounced than in other patients with SMA types 1c or 2.

We identified another FUS variant in exon 5 (c.404G>A; p.S135N). This FUS variant has not been reported before and is predicted to be benign (PolyPhen-2 score 0.004; sensitivity 0.97 , specificity 0.59 ). At the time of inclusion, the patient was aged 19.5 years, and disease course did not differ from what was expected in SMA type 2a. Disease onset was at 6 months, and she carried 3 SMN2 copies. She started with noninvasive respiratory support at age 12 years. Her elder brother, aged 22.5 years at the time of inclusion, also carried 3 SMN2 copies but lacked the variant in FUS. He had an SMA type $2 \mathrm{~b}$ phenotype reaching an additional motor milestone, i.e., standing with support, and did not need respiratory support at age 26 years (last follow-up).

\section{Genetic variation in PFN2 and TDP-43}

No exonic variants could be confirmed in PFN2 or TDP-43. We identified 3 heterozygous, intronic variants in PFN2 and TDP43 (table e-1, links.lww.com/NXG/A202). The A/C variant in intron 2 of PFN2 is located in an ESS, although none of the variants were predicted to alter splicing (HumanSpliceFinder).

\section{Variation in intronic sequences and expression levels of PLS3}

We identified a total of 8 intronic variants in PLS3 (table e-1, links.lww.com/NXG/A202) but no exonic or coding variants. We found 5 variants in 26 patients, affecting ESS sites (c.748+130G>A; c.891-25TC (rs145269469); c.1377+17$\mathrm{A}>\mathrm{G}(\mathrm{rs} 150802596) ; \mathrm{c} .1511+82 \mathrm{~T}>\mathrm{C})$ or creating new ESE sites $\quad$ c. $367+182 \mathrm{C}>\mathrm{T} ; \quad$ c. $1511+82 \mathrm{~T}>\mathrm{C} ; \quad$ c. $891-25 \mathrm{~T}>\mathrm{C}$ (rs145269469)) (figure 1). The c.1511+82T $>\mathrm{C}$ variant occurred in 4 patients, 3 of whom carried a second variant $(c .1511+82 \mathrm{~T}>\mathrm{C}$ and $\mathrm{c} .367+182 \mathrm{C}>\mathrm{T})$. None of these sites was predicted to have an effect on splicing (HumanSpliceFinder), although the functional effect of each variant on
ESS/ESE would remain to be determined. Minor allele frequency was between 0.006 and 0.040 in all variants (Project MinE databrowser, gnomAD, ExAC).

To analyze potential effects of these variants on PLS3 expression levels, we performed expression analysis in blood of patients for which RNA had been collected. Expression analysis was performed in 50 patients and 21 healthy controls (table 1). Healthy controls (median age 68 years [range $38-78$ years $]$ ) included 6 females (29\%). Expression levels of PLS3 ranged from 1.4-26.0 copies/ng copyDNA (cDNA) (median 10.6, mean 10.8). Expression levels did not differ between patients and controls $(p=0.6$; median level in patients: 10.2 copies/ng cDNA [range $1.7-26.0$ copies/ng cDNA]; median level in controls: 12.2 copies/ng cDNA [range 1.4-18.0 copies/ng cDNA]), nor between males and females (controls $p=0.8$; patients with SMA $p=0.9$ ) (figure $2 \mathrm{~A})$. In patients, PLS3 expression levels correlated with age in males $(\mathrm{n}=24)$ (Spearman rho $-0.44 ; p=0.03)$, but not in females $(\mathrm{n}=26)$ (Spearman rho $-0.17, p=0.41)$. There was no correlation between PLS3 levels and the SMN2 copy number $(p=0.32)$.

Figure 1 Reads of variants in $P L S 3$

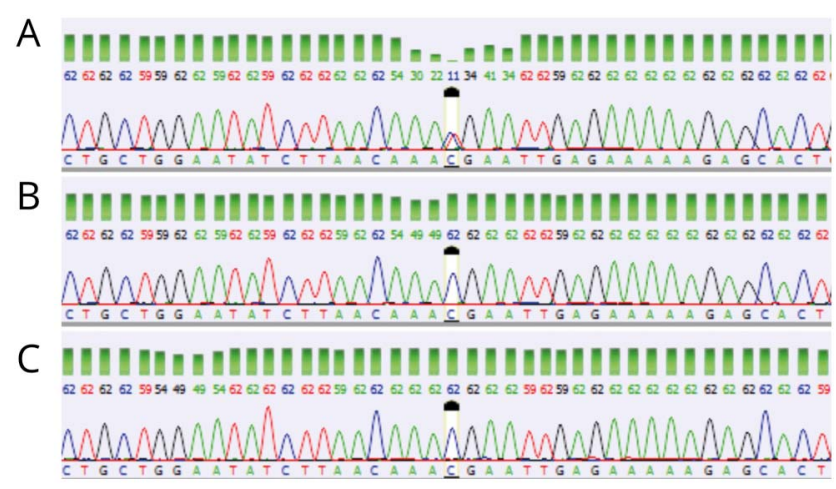

Results showing reverse reads of Sanger sequencing genomic DNA. (A) Heterozygous variant in intron 3 (c.367+182 C>T) in a female patient. (B) No variant in sequence of the brother, who has a milder phenotype. (C) Contro with wild-type sequence. 
Expression levels in patients carrying the variant in intron 3 $(c .367+182 \mathrm{C}>\mathrm{T})$ were higher compared with patients not carrying the variant (figure $2 \mathrm{~B})(p=0.04)$, possibly indicating a functional effect of this variant as a novel ESE. Other variants were not associated with expression changes. We could not perform expression analysis in patients with the c.1511+82$\mathrm{T}>\mathrm{C}$ variant because RNA was not available.

\section{PLS3 genotype and expression levels in relation to clinical phenotypes}

Nineteen nonrelated patients carried 1 of the 5 identified intronic variants in PLS3 affecting an ESE or ESS. The presence of one of the PLS3 variants was not associated with a milder or more severe phenotype in these patients compared with patients without a variant $(p>0.05)$. Six of 27 patients with a discordant phenotype carried an intronic mutation in PLS3, but the presence of a mutation did not correlate with a positive or negative discordant phenotype (all mutations $p$ adjusted $>0.05$ ). PLS3 expression levels did not correlate with clinical severity, e.g., SMA type $(p=0.15)$.

Combined analysis of PLS3 sequences and PLS3 expression analysis was possible in all siblings of 3 families and 7 nonrelated patients (figure 2). Expression levels of PLS3 were not associated with milder or more severe clinical phenotypes $(p=0.53$; figure $2 \mathrm{~B}$. $)$
In 1 family, the presence of the $c .367+182 \mathrm{C}>\mathrm{T}$ variant corresponded with a more severe phenotype or disease course compared with the sibling not carrying the variant (type $2 b$ vs $3 a$ ), whereas in another family, the variant was present in the sibling with a milder phenotype (type $2 b$ vs 1c) (figure 2). In the third family carrying this variant, there was no clear effect of the variant. The siblings had SMA type $3 \mathrm{a}$ in line with 4 SMN2 copies, whereas their cousin had a more severe phenotype (type $2 \mathrm{a}$ ), which corresponded with his 3 SMN2 copy background. In conclusion, these findings suggest that variability in PLS3 sequence and RNA expression does not sufficiently explain discordant severity in our patient cohort.

\section{Discussion}

We performed a hypothesis-based mutational analysis of the candidate disease-modifying genes PLS3, TDP-43, PFN2, and FUS to explore their potential contribution to variability in severity of SMA. We found no evidence for genetic association between variation in these candidate genes and SMA severity, although we identified specific variants in FUS and PLS3 that may be of interest in specific cases. Our findings suggest that other genetic modifiers, both near the SMN locus and elsewhere in the genome, are likely to exist that modify SMA disease severity.

Figure 2 Expression levels of PLS3

A

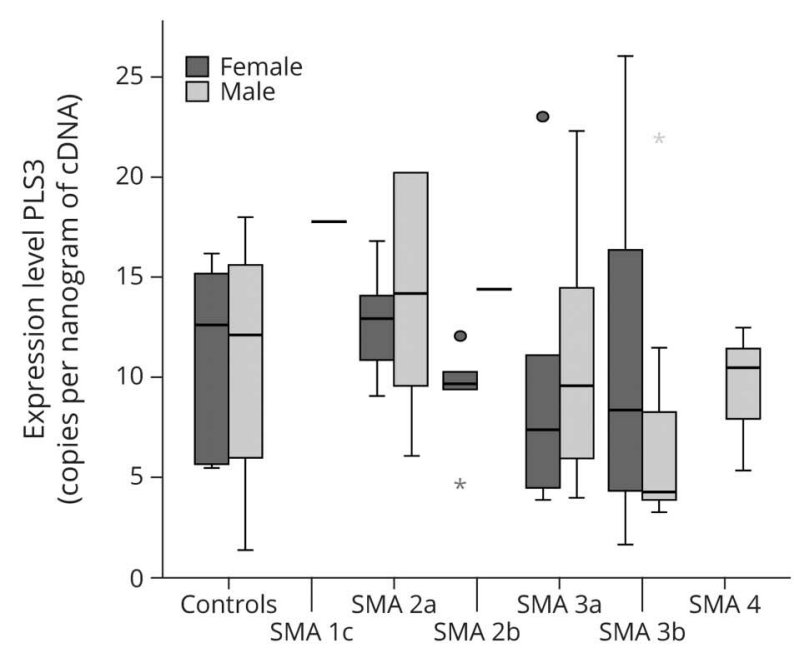

B

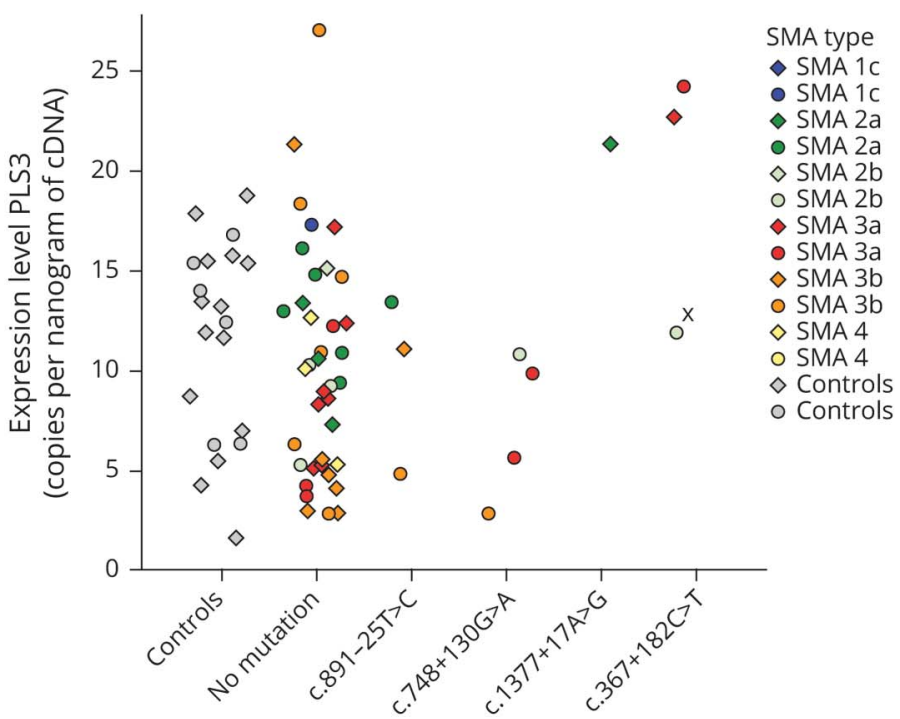

Results showing expression levels of PLS3 and the effects of (A) sex in patients and controls and (B) different intronic variants in the PLS3 gene. Expression levels of PLS3 are expressed in copies per nanogram CDNA. TBP and HRPT1 were both used as references. Variant status of the included controls is unknown. (A) Sex did not consistently affect expression levels in patients or controls $(p=0.5)$. Expression levels of PLS3 did not differ between patients and controls ( $p=$ 0.6 ) or SMA types $(p=0.4)$. (B) Patients are reflected by diamond (male) or bullet (female) with color representing SMA type. Variants in intron 3 (c.367+182C $>$ T) result in higher levels of PLS3 ( $p=0.04$; median expression levels of PLS3 in patients and controls 10.8 copies per nanogram cDNA (range $1.4-26.0$ copies per nanogram CDNA); median expression in intron 3 altered patients 19.1 copies per nanogram cDNA (range $12.1-23.0$ copies per nanogram cDNA). Two siblings of a family carrying the c.367+182C $>$ T variant showed a more severe phenotype (type $2 \mathrm{~b}$ ) in the sibling carrying the variant compared with the sibling who did not carry the variant (type 3a). The expression levels of PLS3 were only available from the sibling with the variant (marked by " $\mathrm{X}^{\prime \prime}$ ). Another family carrying this variant included 2 siblings and their cousin, all carrying the same variant, but having different SMA types (type 3a [siblings] and type 2a [cousin]). The siblings had similar expression levels of PLS3 (marked by “*”). PLS3 expression level in the cousin was not available. CDNA= copy DNA; SMA = spinal muscular atrophy. 
Mutations in FUS exons 5 and 6 have been reported previously in patients with lower motor neuron diseases. ${ }^{21,23,25,26}$ More specifically, the p.R216C mutation was previously described in patients with sporadic ALS or patients with essential tremor. ${ }^{21,24}$ The p.S135N variant has not been described before, and it appears unlikely that this variant is damaging, although the functionality of this particular region of FUS is unknown. ${ }^{25,26}$ FUS and SMN proteins are known to interact and are both involved in RNA processing. ${ }^{14}$ Of interest, deleterious effects of FUS mutations, e.g., dysfunctional axonal growth and branching defects, can be rescued by overexpression of SMN. ${ }^{14}$ The p.R216C mutation may negatively affect FUS expression or the interaction with SMN and thereby further reduce the functionality of the SMN-FUS complex. ${ }^{21}$ Partial penetrance of FUS mutations has been shown by noncomplete disease segregation in familial ALS. ${ }^{25}$ However, because the SMN2 copy number of our patient harboring the p.R216C mutation was in line with the clinical phenotype, the effect of the FUS variant cannot at present be further speculated on.

We did not find coding variants in PFN2 in our cohort of patients. The SMN/PFN2a interaction has been confirmed by previous in vivo studies ${ }^{27}$ showing alternating levels of PFN2a and SMN to effect SMA phenotype in mice. Previous studies showed that minimal changes in protein levels of either SMN or PFN2 altered their interaction and the downstream RhoA/ROCK pathway and affected neuritogenesis. ${ }^{27}$ Although we did not find variants in PFN2, the fact that heterozygous deletions of $S M N 1$ with point mutations in exon 5 containing the binding site for profilin ${ }^{28-32}$ results in an SMA phenotype supports the importance of the SMN/ PFN2a interaction. Second, mutations in other profilins (like profilin-1) contribute to the risk of ALS, ${ }^{19}$ but because of variable penetrance of the mutations, ${ }^{19,20}$ it is as yet unclear whether such mutations are a direct cause or a risk factor for the development of motor neuron disease.

The modifying effect of PLS3 overexpression on SMA phenotype was first suggested by the finding of high PLS3 expression in lymphoblast cells from peripheral blood in a family with asymptomatic or mildly affected females with a homozygous SMN1 deletion. ${ }^{13,33,34}$ Studies in SMA mice and zebrafish supported the role of PLS3 overexpression as shown by the rescue of motor axon defects, ${ }^{22,35,36}$ improvement of neuromuscular junction alterations, ${ }^{8,22,35}$ and prolongation of survival. ${ }^{8,37}$ Other reports showed conflicting results, which may suggest that PLS3 only acts as a modifier in specific families or genetic backgrounds. ${ }^{10,33,34,38-40}$ We identified 5 intronic variants in PLS3 that alter splice sites and may thereby modify clinical severity. Because the severity of modifying effects of PLS3 has been linked to high expression levels, we first studied the relation between these variants and expression, followed by comparison of severity in patients with and without PLS3 variants. One of the challenges of PLS3 expression analysis is the low expression levels in blood, which has also been reported by other groups. ${ }^{38,39}$ We used a sensitive droplet digital PCR technique that requires only small amounts of blood to overcome this issue, but we cannot exclude the possibility that even this technique lacks the sensitivity to detect biologically relevant differences in PLS3 expression, at least in blood. An alternative approach, for example, the use of fibroblasts rather than blood was not possible. PLS3 expression levels were higher in patients with intron $3($ c. $367+182 \mathrm{C}>\mathrm{T})$ variant, but not in any of the other variants. We have analyzed full-length PLS3 transcripts as described previously, ${ }^{13}$ although this approach precludes the analysis of correlations between specific mutations and alternative (unknown) isoforms of PLS3 and might therefore have resulted in the lack of correlation between phenotype and expression levels. A further comparison of severity between patients with and without PLS3 variants did not show a consistent correlation with disease severity, with the notable exception of 1 family, where the intron 3 $(c .367+182 \mathrm{C}>\mathrm{T})$ variation coincided with a more severe rather than a milder disease course. This finding is clearly not in line with the presumed protective effect of higher PLS3 expression levels. Combined, our data suggest that specific rare variants in PLS3 may alter expression levels, but the effect on the clinical phenotype remains unclear.

In the current study, we chose to study a small number of candidate genes in high detail. Because we used targeted nextgeneration sequencing analysis in our initial screen for variants, we may have missed individual mutational changes that cannot be detected by the designed amplicons. Moreover, genetic variants further up- or downstream of our candidate genes are not included in the current study but may be required to further explain variation in e.g., PLS3 RNA expression. Common variants near modifying genes might affect clinical severity, but were not explored in this study. Wholegenome sequencing approaches might aid in the discovery of other disease-modifying variants, although the identification of predictors for individual patients or small numbers of patients might be complicated by a lack of statistical power that these kind of studies generally require.

The identification and registration of the present (dis)cordant families with multiple affected siblings or first- or seconddegree relatives is essential in the identification of possible disease severity modifiers, especially now that such families will become increasingly rare due to the introduction of presymptomatic treatment strategies, prenatal screening, or even preimplantation selection. Larger studies through international collaborative efforts in search for genetic modifiers are needed, especially now that genetic modifiers such as $S M N 2$ have become potent targets for therapeutic strategies and may help to identify those who benefit most from these intensive therapies.

\section{Acknowledgment}

The authors are grateful to the patients and families who participated in this study and to the Dutch patient organization for neuromuscular diseases (Spierziekten Nederland) that supported its initiation and execution. 


\section{Study funding}

This work was supported by a grant from the Prinses Beatrix Spierfonds (WAR08-24).

\section{Disclosure}

Disclosures available: Neurology.org/NG.

\section{Publication history}

Received by Neurology: Genetics June 11, 2019. Accepted in final form November 4, 2019.

Appendix Authors

\begin{tabular}{|c|c|c|c|}
\hline Name & Location & Role & Contribution \\
\hline $\begin{array}{l}\text { Renske I. } \\
\text { Wadman, } \\
\text { MD, PhD }\end{array}$ & $\begin{array}{l}\text { Department of } \\
\text { Neurology, Brain } \\
\text { Center Rudolf } \\
\text { Magnus, University } \\
\text { Medical Center } \\
\text { Utrecht, The } \\
\text { Netherlands }\end{array}$ & Author & $\begin{array}{l}\text { Designed and } \\
\text { conceptualized } \\
\text { the study, analyzed } \\
\text { the data, interpreted } \\
\text { the data, and } \\
\text { drafted and revised } \\
\text { the manuscript for } \\
\text { intellectual } \\
\text { content }\end{array}$ \\
\hline $\begin{array}{l}\text { Marc D. } \\
\text { Jansen, BS }\end{array}$ & $\begin{array}{l}\text { Department of } \\
\text { Neurology, Brain } \\
\text { Center Rudolf } \\
\text { Magnus, University } \\
\text { Medical Center } \\
\text { Utrecht, The } \\
\text { Netherlands }\end{array}$ & Author & $\begin{array}{l}\text { Designed and } \\
\text { conceptualized the } \\
\text { study, analyzed the } \\
\text { data, and revised } \\
\text { the manuscript for } \\
\text { intellectual content }\end{array}$ \\
\hline $\begin{array}{l}\text { Chantall } \\
\text { A.D. Curial, } \\
\text { BS }\end{array}$ & $\begin{array}{l}\text { Department of } \\
\text { Neurology, Brain } \\
\text { Center Rudolf } \\
\text { Magnus, University } \\
\text { Medical Center } \\
\text { Utrecht, The } \\
\text { Netherlands }\end{array}$ & Author & $\begin{array}{l}\text { Major role in the } \\
\text { acquisition of the } \\
\text { data and revision of } \\
\text { the manuscript for } \\
\text { intellectual content }\end{array}$ \\
\hline $\begin{array}{l}\text { Ewout J.N. } \\
\text { Groen, PhD }\end{array}$ & $\begin{array}{l}\text { Department of } \\
\text { Neurology, Brain } \\
\text { Center Rudolf } \\
\text { Magnus, University } \\
\text { Medical Center } \\
\text { Utrecht, The } \\
\text { Netherlands }\end{array}$ & Author & $\begin{array}{l}\text { Interpreted the data } \\
\text { and revised the } \\
\text { manuscript for } \\
\text { intellectual content }\end{array}$ \\
\hline $\begin{array}{l}\text { Marloes } \\
\text { Stam, MD }\end{array}$ & $\begin{array}{l}\text { Department of } \\
\text { Neurology, Brain } \\
\text { Center Rudolf } \\
\text { Magnus, University } \\
\text { Medical Center } \\
\text { Utrecht, The } \\
\text { Netherlands }\end{array}$ & Author & $\begin{array}{l}\text { Acquired the data } \\
\text { and revised the } \\
\text { manuscript for } \\
\text { intellectual content }\end{array}$ \\
\hline $\begin{array}{l}\text { Camiel A. } \\
\text { Wijngaarde, } \\
\text { MD }\end{array}$ & $\begin{array}{l}\text { Department of } \\
\text { Neurology, Brain } \\
\text { Center Rudolf } \\
\text { Magnus, University } \\
\text { Medical Center } \\
\text { Utrecht, The } \\
\text { Netherlands }\end{array}$ & Author & $\begin{array}{l}\text { Acquired the data } \\
\text { and revised the } \\
\text { manuscript for } \\
\text { intellectual content }\end{array}$ \\
\hline $\begin{array}{l}\text { Jelena } \\
\text { Medic, BS }\end{array}$ & $\begin{array}{l}\text { Department of } \\
\text { Neurology, Brain } \\
\text { Center Rudolf } \\
\text { Magnus, University } \\
\text { Medical Center } \\
\text { Utrecht, The } \\
\text { Netherlands }\end{array}$ & Author & $\begin{array}{l}\text { Acquired the data } \\
\text { and revised the } \\
\text { manuscript for } \\
\text { intellectual content }\end{array}$ \\
\hline
\end{tabular}

Appendix (continued)

\begin{tabular}{|c|c|c|c|}
\hline Name & Location & Role & Contribution \\
\hline $\begin{array}{l}\text { Peter } \\
\text { Sodaar, BS }\end{array}$ & $\begin{array}{l}\text { Department of } \\
\text { Neurology, Brain } \\
\text { Center Rudolf } \\
\text { Magnus, University } \\
\text { Medical Center } \\
\text { Utrecht, The } \\
\text { Netherlands }\end{array}$ & Author & $\begin{array}{l}\text { Acquired the data } \\
\text { and revised the } \\
\text { manuscript for } \\
\text { intellectual content }\end{array}$ \\
\hline $\begin{array}{l}\text { Kristel R. } \\
\text { van Eijk, } \\
\text { PhD }\end{array}$ & $\begin{array}{l}\text { Department of } \\
\text { Neurology, Brain } \\
\text { Center Rudolf } \\
\text { Magnus, University } \\
\text { Medical Center } \\
\text { Utrecht, The } \\
\text { Netherlands }\end{array}$ & Author & $\begin{array}{l}\text { Designed and } \\
\text { conceptualized the } \\
\text { study, major role in } \\
\text { analysing and } \\
\text { interpreting the data, } \\
\text { and revised the } \\
\text { manuscript for } \\
\text { intellectual content }\end{array}$ \\
\hline $\begin{array}{l}\text { Manon M.H. } \\
\text { Huibers, } \\
\text { PhD }\end{array}$ & $\begin{array}{l}\text { Department of } \\
\text { Pathology \& } \\
\text { Department of } \\
\text { Genetics, University } \\
\text { Medical Center } \\
\text { Utrecht, The } \\
\text { Netherlands }\end{array}$ & Author & $\begin{array}{l}\text { Acquired the data } \\
\text { and revised the } \\
\text { manuscript for } \\
\text { intellectual content }\end{array}$ \\
\hline $\begin{array}{l}\text { Joyce van } \\
\text { Kuik, BS }\end{array}$ & $\begin{array}{l}\text { Department of } \\
\text { Pathology, University } \\
\text { Medical Center } \\
\text { Utrecht, The } \\
\text { Netherlands }\end{array}$ & Author & $\begin{array}{l}\text { Acquired the data } \\
\text { and revised the } \\
\text { manuscript for } \\
\text { intellectual content }\end{array}$ \\
\hline $\begin{array}{l}\text { Henny H. } \\
\text { Lemmink, } \\
\text { MD, PhD }\end{array}$ & $\begin{array}{l}\text { Department of } \\
\text { Genetics, University } \\
\text { Medical Center } \\
\text { Groningen, The } \\
\text { Netherlands }\end{array}$ & Author & $\begin{array}{l}\text { Acquired the data } \\
\text { and revised the } \\
\text { manuscript for } \\
\text { intellectual content }\end{array}$ \\
\hline $\begin{array}{l}\text { Wouter van } \\
\text { Rheenen, } \\
\text { MD, PhD }\end{array}$ & $\begin{array}{l}\text { Department of } \\
\text { Neurology, Brain } \\
\text { Center Rudolf } \\
\text { Magnus, University } \\
\text { Medical Center } \\
\text { Utrecht, The } \\
\text { Netherlands }\end{array}$ & Author & $\begin{array}{l}\text { Interpreted the data } \\
\text { and revised the } \\
\text { manuscript for } \\
\text { intellectual content }\end{array}$ \\
\hline $\begin{array}{l}\text { Jan Herman } \\
\text { Veldink, MD, } \\
\text { PhD }\end{array}$ & $\begin{array}{l}\text { Department of } \\
\text { Neurology, Brain } \\
\text { Center Rudolf } \\
\text { Magnus, University } \\
\text { Medical Center } \\
\text { Utrecht, The } \\
\text { Netherlands }\end{array}$ & Author & $\begin{array}{l}\text { Designed and } \\
\text { conceptualized the } \\
\text { study, analysing and } \\
\text { interpreting the data, } \\
\text { and revised the } \\
\text { manuscript for } \\
\text { intellectual content }\end{array}$ \\
\hline $\begin{array}{l}\text { Leonard H. } \\
\text { van den } \\
\text { Berg, MD, } \\
\text { PhD }\end{array}$ & $\begin{array}{l}\text { Department of } \\
\text { Neurology, Brain } \\
\text { Center Rudolf } \\
\text { Magnus, University } \\
\text { Medical Center } \\
\text { Utrecht, The } \\
\text { Netherlands }\end{array}$ & Author & $\begin{array}{l}\text { Acquired and } \\
\text { interpreted the data } \\
\text { and revised the } \\
\text { manuscript for } \\
\text { intellectual content }\end{array}$ \\
\hline $\begin{array}{l}\text { W. Ludo van } \\
\text { der Pol, MD, } \\
\text { PhD }\end{array}$ & $\begin{array}{l}\text { Department of } \\
\text { Neurology, Brain } \\
\text { Center Rudolf } \\
\text { Magnus, University } \\
\text { Medical Center } \\
\text { Utrecht, The } \\
\text { Netherlands }\end{array}$ & Author & $\begin{array}{l}\text { Designed and } \\
\text { conceptualized the } \\
\text { study, analyzed the } \\
\text { data, and drafted and } \\
\text { revised the } \\
\text { manuscript for } \\
\text { intellectual content }\end{array}$ \\
\hline
\end{tabular}

\section{References}

1. Lefebvre S, Burglen L, Reboullet S, et al. Identification and characterization of a spinal muscular atrophy-determining gene. Cell 1995;80:155-165.

2. Mercuri E, Bertini E, Iannaccone ST. Childhood spinal muscular atrophy: controversies and challenges. Lancet Neurol 2012;11:443-452. 
3. Lefebvre S, Burlet P, Liu Q, et al. Correlation between severity and SMN protein level in spinal muscular atrophy. Nat Genet 1997;16:265-269.

4. Wishart TM, Mutsaers CA, Riessland M, et al. Dysregulation of ubiquitin homeostasis and beta-catenin signaling promote spinal muscular atrophy. J Clin Invest 2014;124: 1821-1834.

5. Burghes AH, Beattie CE. Spinal muscular atrophy: why do low levels of survival motor neuron protein make motor neurons sick? Nat Rev Neurosci 2009;10:597-609.

6. Rossoll W, Jablonka S, Andreassi C, et al. Smn, the spinal muscular atrophydetermining gene product, modulates axon growth and localization of beta-actin mRNA in growth cones of motoneurons. J Cell Biol 2003;163:801-812.

7. McWhorter ML, Monani UR, Burghes AH, Beattie CE. Knockdown of the survival motor neuron $(\mathrm{Smn})$ protein in zebrafish causes defects in motor axon outgrowth and pathfinding. J Cell Biol 2003;162:919-931.

8. Hosseinibarkooie S, Peters M, Torres-Benito L, et al. The power of human protective modifiers: PLS3 and CORO1C unravel impaired endocytosis in spinal muscular atrophy and rescue SMA phenotype. Am J Hum Genet 2016;99:647-665.

9. Calucho M, Bernal S, Alias L, et al. Correlation between SMA type and SMN2 copy number revisited: an analysis of 625 unrelated Spanish patients and a compilation of 2834 reported cases. Neuromuscul Disord 2018;28:208-215.

10. Ruhno C, McGovern VL, Avenarius MR, et al. Complete sequencing of the SMN2 gene in SMA patients detects SMN gene deletion junctions and variants in SMN2 that modify the SMA phenotype. Hum Genet 2019;138:241-256.

11. Prior TW, Krainer AR, Hua Y, et al. A positive modifier of spinal muscular atrophy in the SMN2 gene. Am J Hum Genet 2009;85:408-413.

12. Hauke J, Riessland M, Lunke S, et al. Survival motor neuron gene 2 silencing by DNA methylation correlates with spinal muscular atrophy disease severity and can be bypassed by histone deacetylase inhibition. Hum Mol Genet 2009;18:304-317.

13. Oprea GE, Krober S, McWhorter ML, et al. Plastin 3 is a protective modifier of autosomal recessive spinal muscular atrophy. Science 2008;320:524-527.

14. Groen EJ, Fumoto K, Blokhuis AM, et al. ALS-associated mutations in FUS disrupt the axonal distribution and function of SMN. Hum Mol Genet 2013;22:3690-3704.

15. Kapeli K, Pratt GA, Vu AQ, et al. Distinct and shared functions of ALS-associated proteins TDP-43, FUS and TAF15 revealed by multisystem analyses. Nat Commun 2016;7:12143.

16. Tanaka Y, Hasegawa M. Profilin 1 mutants form aggregates that induce accumulation of prion-like TDP-43. Prion 2016;10:283-289.

17. Bowerman M, Anderson CL, Beauvais A, Boyl PP, Witke W, Kothary R. SMN, profilin IIa and plastin 3: a link between the deregulation of actin dynamics and SMA pathogenesis. Mol Cell Neurosci 2009;42:66-74.

18. Nolle A, Zeug A, van Bergeijk J, et al. The spinal muscular atrophy disease protein SMN is linked to the Rho-kinase pathway via profilin. Hum Mol Genet 2011;20:4865-4878.

19. Wu CH, Fallini $\mathrm{C}$, Ticozzi N, et al. Mutations in the profilin 1 gene cause familial amyotrophic lateral sclerosis. Nature 2012;488:499-503.

20. Fratta P, Charnock J, Collins T, et al. Profilin1 E117G is a moderate risk factor for amyotrophic lateral sclerosis. J Neurol Neurosurg Psychiatry 2014;85:506-508.

21. Corrado L, Del Bo R, Castellotti B, et al. Mutations of FUS gene in sporadic amyotrophic lateral sclerosis. J Med Genet 2010;47:190-194.

22. Ackermann B, Krober S, Torres-Benito L, et al. Plastin 3 ameliorates spinal muscular atrophy via delayed axon pruning and improves neuromuscular junction functionality. Hum Mol Genet 2013;22:1328-1347.
23. Kwiatkowski TJ Jr, Bosco DA, Leclerc AL, et al. Mutations in the FUS/TLS gene on chromosome 16 cause familial amyotrophic lateral sclerosis. Science 2009;323: $1205-1208$.

24. Merner ND, Girard SL, Catoire $\mathrm{H}$, et al. Exome sequencing identifies FUS mutations as a cause of essential tremor. Am J Hum Genet 2012;91:313-319.

25. Yan J, Deng HX, Siddique N, et al. Frameshift and novel mutations in FUS in familial amyotrophic lateral sclerosis and ALS/dementia. Neurology 2010;75:807-814.

26. Ticozzi N, Silani V, LeClerc AL, et al. Analysis of FUS gene mutation in familia amyotrophic lateral sclerosis within an Italian cohort. Neurology 2009;73:1180-1185.

27. Hensel N, Claus P. The actin cytoskeleton in SMA and ALS: how does it contribute to motoneuron degeneration? Neuroscientist 2018;24:54-72.

28. Jedrzejowska M, Gos M, Zimowski JG, Kostera-Pruszczyk A, Ryniewicz B, Hausmanowa-Petrusewicz I. Novel point mutations in survival motor neuron 1 gene expand the spectrum of phenotypes observed in spinal muscular atrophy patients. Neuromuscul Disord 2014;24:617-623.

29. Wirth B, Herz M, Wetter A, et al. Quantitative analysis of survival motor neuron copies: identification of subtle SMN1 mutations in patients with spinal muscular atrophy, genotype-phenotype correlation, and implications for genetic counseling. Am J Hum Genet 1999;64:1340-1356.

30. Tsai CH, Jong YJ, Hu CJ, et al. Molecular analysis of SMN, NAIP and P44 genes of SMA patients and their families. J Neurol Sci 2001;190:35-40.

31. Yang L, Cao YY, Qu YJ, et al. Sanger sequencing for the diagnosis of spinal muscular atrophy patients with survival motor neuron gene 1 compound heterozygous mutation [in Chinese]. Zhonghua Yi Xue Za Zhi 2017;97:418-423.

32. $\mathrm{Du} \mathrm{J}, \mathrm{Qu} \mathrm{YJ}$, Xiong $\mathrm{H}$, et al. Mutation analysis of SMN1 gene in patients with spinal muscular atrophy [in Chinese]. Zhonghua Er Ke Za Zhi 2011;49:411-415.

33. Yanyan C, Yujin Q, Jinli B, Yuwei J, Hong W, Fang S. Correlation of PLS3 expression with disease severity in children with spinal muscular atrophy. J Hum Genet 2014;59: 24-27.

34. Stratigopoulos G, Lanzano P, Deng L, et al. Association of plastin 3 expression with disease severity in spinal muscular atrophy only in postpubertal females. Arch Neurol 2010;67:1252-1256.

35. Hao le T, Wolman M, Granato M, Beattie CE. Survival motor neuron affects plastin 3 protein levels leading to motor defects. J Neurosci 2012;32:5074-5084.

36. Lyon AN, Pineda RH, Hao le T, Kudryashova E, Kudryashov DS, Beattie CE. Calcium binding is essential for plastin 3 function in Smn-deficient motoneurons. Hum Mol Genet 2014;23:1990-2004.

37. Kaifer KA, Villalon E, Osman EY, et al. Plastin-3 extends survival and reduces severity in mouse models of spinal muscular atrophy. JCI Insight 2017;2:e89970.

38. Boza-Moran MG, Martinez-Hernandez R, Bernal S, et al. Decay in survival motor neuron and plastin 3 levels during differentiation of iPSC-derived human motor neurons. Sci Rep 2015;5:11696.

39. Bernal S, Also-Rallo E, Martinez-Hernandez R, et al. Plastin 3 expression in discordant spinal muscular atrophy (SMA) siblings. Neuromuscul Disord 2011;21: 413-419.

40. McGovern VL, Massoni-Laporte A, Wang X, et al. Plastin 3 expression does not modify spinal muscular atrophy severity in the 7 SMA mouse. PLoS One 2015;10: e0132364.

41. Coovert DD, Le TT, McAndrew PE, et al. The survival motor neuron protein in spinal muscular atrophy. Hum Mol Genet 1997;6:1205-1214. 


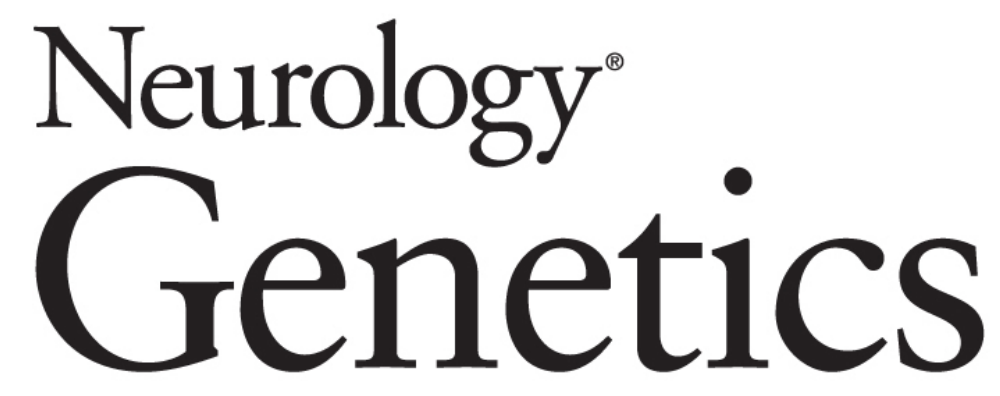

\section{Analysis of $F U S, P F N 2, T D P-43$, and $P L S 3$ as potential disease severity modifiers in spinal muscular atrophy \\ Renske I. Wadman, Marc D. Jansen, Chantall A.D. Curial, et al. \\ Neurol Genet 2020;6; \\ DOI 10.1212/NXG.0000000000000386}

This information is current as of January 3, 2020

Updated Information \&

Services

References

Subspecialty Collections

Permissions \& Licensing

Reprints including high resolution figures, can be found at: http://ng.neurology.org/content/6/1/e386.full.html

This article cites 41 articles, 7 of which you can access for free at: http://ng.neurology.org/content/6/1/e386.full.html\#\#ref-list-1

This article, along with others on similar topics, appears in the following collection(s):

Anterior nerve cell disease

http://ng.neurology.org//cgi/collection/anterior_nerve_cell_disease Association studies in genetics

http://ng.neurology.org//cgi/collection/association_studies_in_genetics Gene expression studies

http://ng.neurology.org//cgi/collection/gene_expression_studies

Information about reproducing this article in parts (figures,tables) or in its entirety can be found online at:

http://ng.neurology.org/misc/about.xhtml\#permissions

Information about ordering reprints can be found online:

http://ng.neurology.org/misc/addir.xhtml\#reprintsus

Neurol Genet is an official journal of the American Academy of Neurology. Published since April 2015, it is an open-access, online-only, continuous publication journal. Copyright Copyright $\odot 2020$ The Author(s). Published by Wolters Kluwer Health, Inc. on behalf of the American Academy of Neurology.. All rights reserved. Online ISSN: 2376-7839.

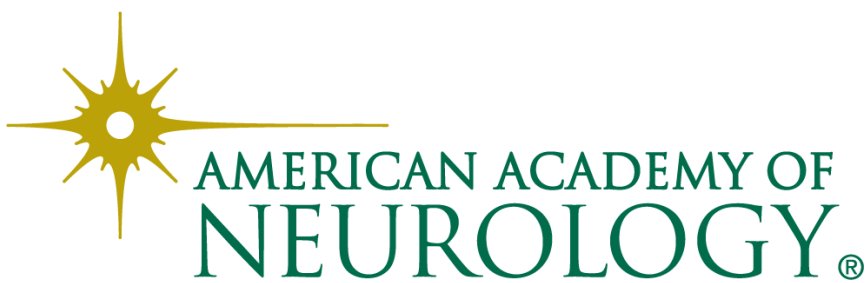

